\title{
ॠUSGS
}

science for a changing world

Precipitation Variability of the Grand Canyon Region, 1893 through 2009, and Its Implications for Studying Effects of Gullying of Holocene Terraces and Associated Archeological Sites in Grand Canyon, Arizona

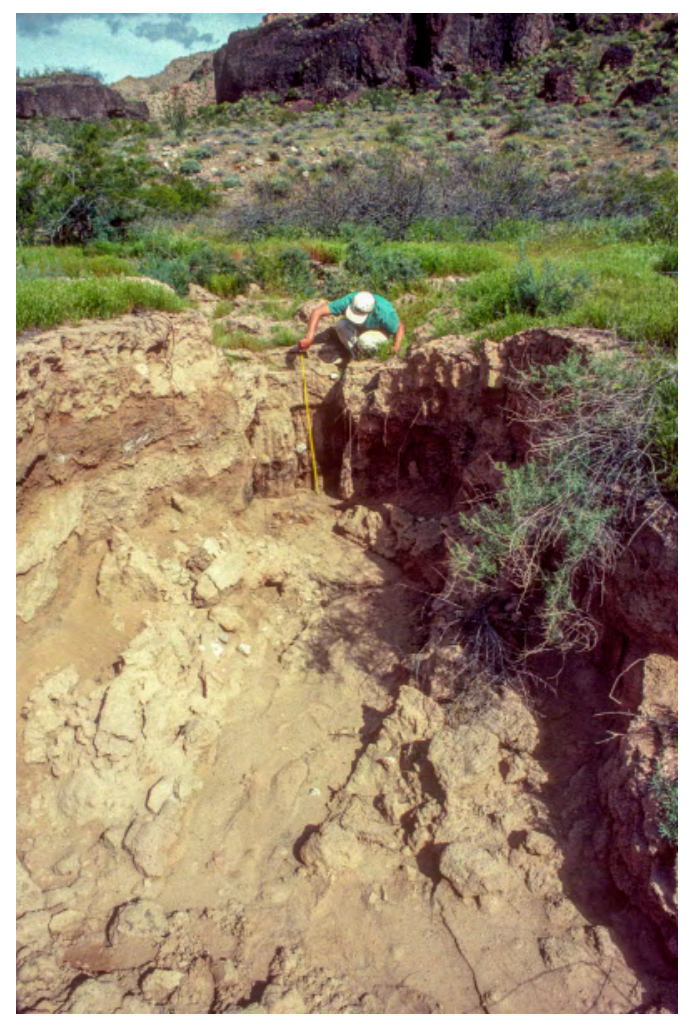

Open-File Report 2014-1006

U.S. Department of the Interior U.S. Geological Survey 
COVER

Photograph showing headcut migration and gullying active shortly before March 1993 during the unusually wet winter of 1992-1993, upper Granite Park area of the western Grand Canyon, Arizona (U.S. Geological Survey photograph by R. Hereford). 


\section{Precipitation Variability of the Grand Canyon Region, 1893 through 2009, and Its Implications for Studying Effects of Gullying of Holocene Terraces and Associated Archeological Sites in Grand Canyon, Arizona}

By Richard Hereford, Glenn E. Bennett, and Helen C. Fairley

Open-File Report 2014-1006

U.S. Department of the Interior

U.S. Geological Survey 


\section{U.S. Department of the Interior \\ SALLY JEWELL, Secretary}

\section{U.S. Geological Survey \\ Suzette M. Kimball, Acting Director}

U.S. Geological Survey, Reston, Virginia: 2014

For product and ordering information:

World Wide Web: http://www.usgs.gov/pubprod

Telephone: 1-888-ASK-USGS

For more information on the USGS-the Federal source for science about the Earth, its natural and living resources, natural hazards, and the environment:

World Wide Web: http://www.usgs.gov

Telephone: 1-888-ASK-USGS

Suggested citation:

Hereford, R., Bennett, G.E., and Fairley, H.C., 2014, Precipitation variability of the Grand Canyon region, 1893

through 2009, and its implications for studying effects of gullying of Holocene terraces and associated archeological sites in Grand Canyon, Arizona: U.S. Geological Survey Open-File Report 2014-1006, 23 p., http://dx.doi.org/10.3133/ofr20141006.

Any use of trade, product, or firm names is for descriptive purposes only and does not imply endorsement by the U.S. Government.

Although this report is in the public domain, permission must be secured from the individual copyright owners to reproduce any copyrighted material contained within this report.

ISSN 2331-1258 (online) 


\section{Contents}

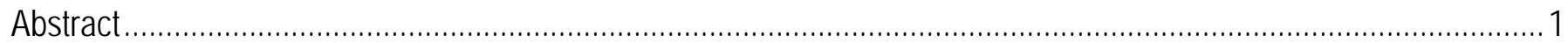

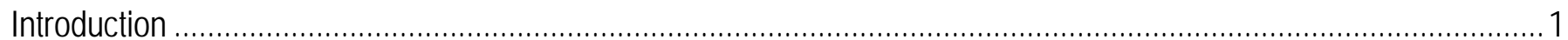

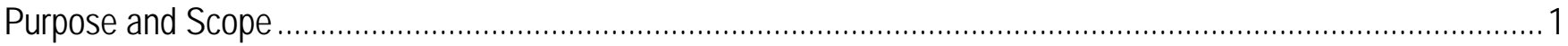

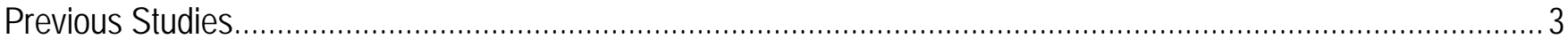

Data

Methods

Water-Year Precipitation of the 13 Climate Divisions .....................................................................................

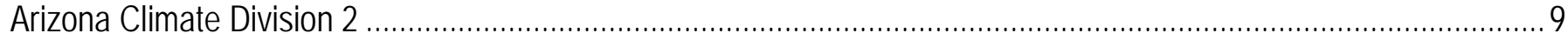

Precipitation Variability in the Grand Canyon Area ....................................................................................... 11

Historic Daily Precipitation in Grand Canyon and on Nearby Rims ..................................................................... 14

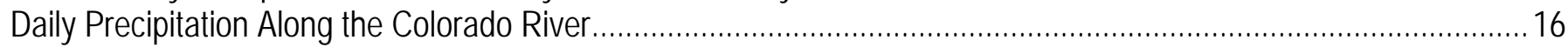

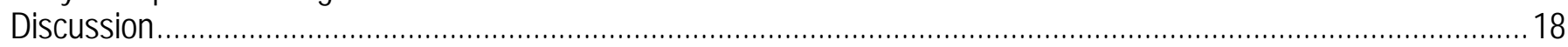

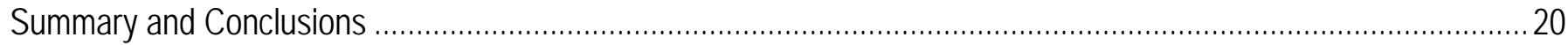

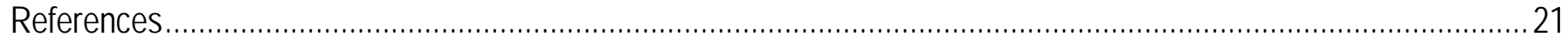

\section{Figures}

Figure 1. Map showing climate divisions and National Weather Service Cooperative Observer Program (COOP) weather stations in the Grand Canyon, Arizona, region of the Southwest United States ................................ 2

Figure 2. Map showing National Weather Service Cooperative Observer Program (COOP) weather stations (yellow circles) in the local Grand Canyon, Arizona, area and automated weather stations (green triangles) along Colorado River in Grand Canyon.

Figure 3. Graph of mean deviation of water-year precipitation from the average total precipitation of individual stations in each of seven climate divisions (a-g; fig. 1 ) of the Colorado Plateau and Central Arizona highlands

Figure 4. Graph of mean deviation of water-year precipitation from the average total precipitation of individual stations in each of, four climate divisions (a-d; fig. 1) of the Mojave Desert region

Figure 5. Graph of mean deviation of water-year precipitation from the average total precipitation of individual stations in each of two climate divisions (a-b; fig. 1), of the Colorado River Basin of the northeast Colorado Plateau and New Mexico Climate Division 2 of the southern Rocky Mountains.

Figure 6. Graph of mean deviation of water-year precipitation showing multidecadal drought and wet episodes for Arizona Climate Division 2

Figure 7. Time series graph showing average number of days annually having precipitation greater than 90th percentile (a measure of daily precipitation intensity) of all precipitation of individual weather stations in Arizona Climate Division 2

Figure 8. Graph showing name, period of record (horizontal lines), and percent missing daily entries of National Weather Service Cooperative Observer Program (COOP) weather stations in the local Grand Canyon area 13

Figure 9. Graph of mean deviation of water-year precipitation from 1950 to 2008 for Grand Canyon, Arizona, area National Weather Service Cooperative Observer Program (COOP) weather stations

Figure 10. Graph showing four daily precipitation time series, 1990 to 2009, of National Weather Service Cooperative Observer Program (COOP) weather stations in Grand Canyon, Arizona, and on the canyon's North and South Rims.

Figure 11. Graph showing daily time series, November 2003 through December 2009, of automated weather stations along the Colorado River corridor in Grand Canyon, Arizona, at 10 archeologically sensitive localities and Phantom Ranch COOP station...

Figure 12. Photograph showing headcut migration and gullying active shortly before March 1993 during the unusually wet winter of 1992-1993, upper Granite Park area of the western Grand Canyon, Arizona 


\section{Tables}

Table 1. National Weather Service Cooperative Observer Program (COOP) weather stations in or near the Grand Canyon, Arizona................................................................................................................................ 12

Table 2. Comparison of daily simultaneous precipitation occurrences for four Grand Canyon, Arizona, National Weather Service Cooperative Observer Program (COOP) weather stations.

\section{Conversion Factors}

SI to Inch/Pound

\begin{tabular}{lll}
\hline \multicolumn{1}{c}{ Multiply } & By & \multicolumn{1}{c}{ To obtain } \\
\hline centimeter $(\mathrm{cm})$ & Length & \\
millimeter (mm) & 0.3937 & inch (in.) \\
meter (m) & 0.03937 & inch (in.) \\
kilometer (km) & 3.281 & foot (ft) \\
meter (m) & 0.6214 & mile (mi) \\
& 1.094 & yard (yd) \\
\hline square meter $\left(\mathrm{m}^{2}\right)$ & Area & \\
hectare (ha) & 10.76 & square foot $\left(\mathrm{ft}^{2}\right)$ \\
square kilometer $\left(\mathrm{km}^{2}\right)$ & 0.003861 & square mile $\left(\mathrm{mi}^{2}\right)$ \\
\hline
\end{tabular}

Inch/Pound to SI

\begin{tabular}{lcl}
\hline & \multicolumn{1}{c}{ Multiply } & \multicolumn{1}{c}{ To obtain } \\
\hline inch (in.) & Length & \\
inch (in.) & 2.54 & centimeter (cm) \\
foot (ft) & 25.4 & millimeter (mm) \\
mile (mi) & 0.3048 & meter (m) \\
yard (yd) & 1.609 & kilometer $(\mathrm{km})$ \\
\hline & 0.9144 & meter (m) \\
\hline square foot $\left(\mathrm{ft}^{2}\right)$ & Area & \\
square mile $\left(\mathrm{mi}^{2}\right)$ & 0.09290 & square meter $\left(\mathrm{m}^{2}\right)$ \\
square mile $\left(\mathrm{mi}^{2}\right)$ & 259.0 & hectare (ha) \\
\hline
\end{tabular}




\title{
Precipitation Variability of the Grand Canyon Region, 1893 through 2009, and Its Implications for Studying Effects of Gullying on Holocene Terraces and Associated Archeological Sites in Grand Canyon, Arizona
}

\author{
By Richard Hereford, Glenn E. Bennett, and Helen C. Fairley
}

\begin{abstract}
A daily precipitation dataset covering a large part of the American Southwest was compiled for online electronic distribution (http://pubs.usgs.gov/of/2014/1006/). The dataset contains 10.8 million observations spanning January 1893 through January 2009 from 846 weather stations in six states and 13 climate divisions. In addition to processing the data for distribution, water-year totals and other statistical parameters were calculated for each station with more than 2 years of observations. Divisionwide total precipitation, expressed as the average deviation from the individual station means of a climate division, shows that the region-including the Grand Canyon, Arizona, area — has been affected by alternating multidecadal episodes of drought and wet conditions.

In addition to compiling and analyzing the long-term regional precipitation data, a second dataset consisting of high-temporal-resolution precipitation measurements collected between November 2003 and January 2009 from 10 localities along the Colorado River in Grand Canyon was compiled. An exploratory study of these high-temporal-resolution precipitation measurements suggests that on a daily basis precipitation patterns are generally similar to those at a long-term weather station in the canyon, which in turn resembles the patterns at other long-term stations on the canyon rims; however, precipitation amounts recorded by the individual inner canyon weather stations can vary substantially from station to station. Daily and seasonal rainfall patterns apparent in these data are not random. For example, the inner canyon record, although short and fragmented, reveals three episodes of widespread, heavy precipitation in late summer 2004, early winter 2005, and summer 2007. The 2004 event and several others had sufficient rainfall to initiate potentially pervasive erosion of the late Holocene terraces and related archeological features located along the Colorado River in Grand Canyon.
\end{abstract}

\section{Introduction}

\section{Purpose and Scope}

The primary purpose of this project was to assemble and disseminate historical and current records of daily precipitation in and surrounding the Grand Canyon (fig. 1). A secondary goal was an exploratory evaluation of the synchronicity of climate patterns as revealed by analysis of annual and daily precipitation. In this study, we explore the climate variability of the study area with a specially compiled dataset consisting of daily precipitation values from 846 weather stations spread across the Grand Canyon region of the American Southwest (fig. 1). In addition, we compiled high-resolution weather data from 10 automated weather stations located along the Colorado River within Grand 
Canyon, Arizona, and maintained by the U.S. Geological Survey (USGS) Grand Canyon Monitoring and Research Center (GMRC) between 2007 and 2009 (fig. 2). Taken together, these data span 117 years from 1893 through 2009 (dataset available online at http://pubs.usgs.gov/of/2014/1006/). Although exploratory in nature, results presented here suggest that multidecadal patterns of precipitation variability have affected the climate of the local Grand Canyon area much as they have the southern Colorado Plateau and adjacent Mojave Desert (Hereford and others, 2002, 2003, 2006).

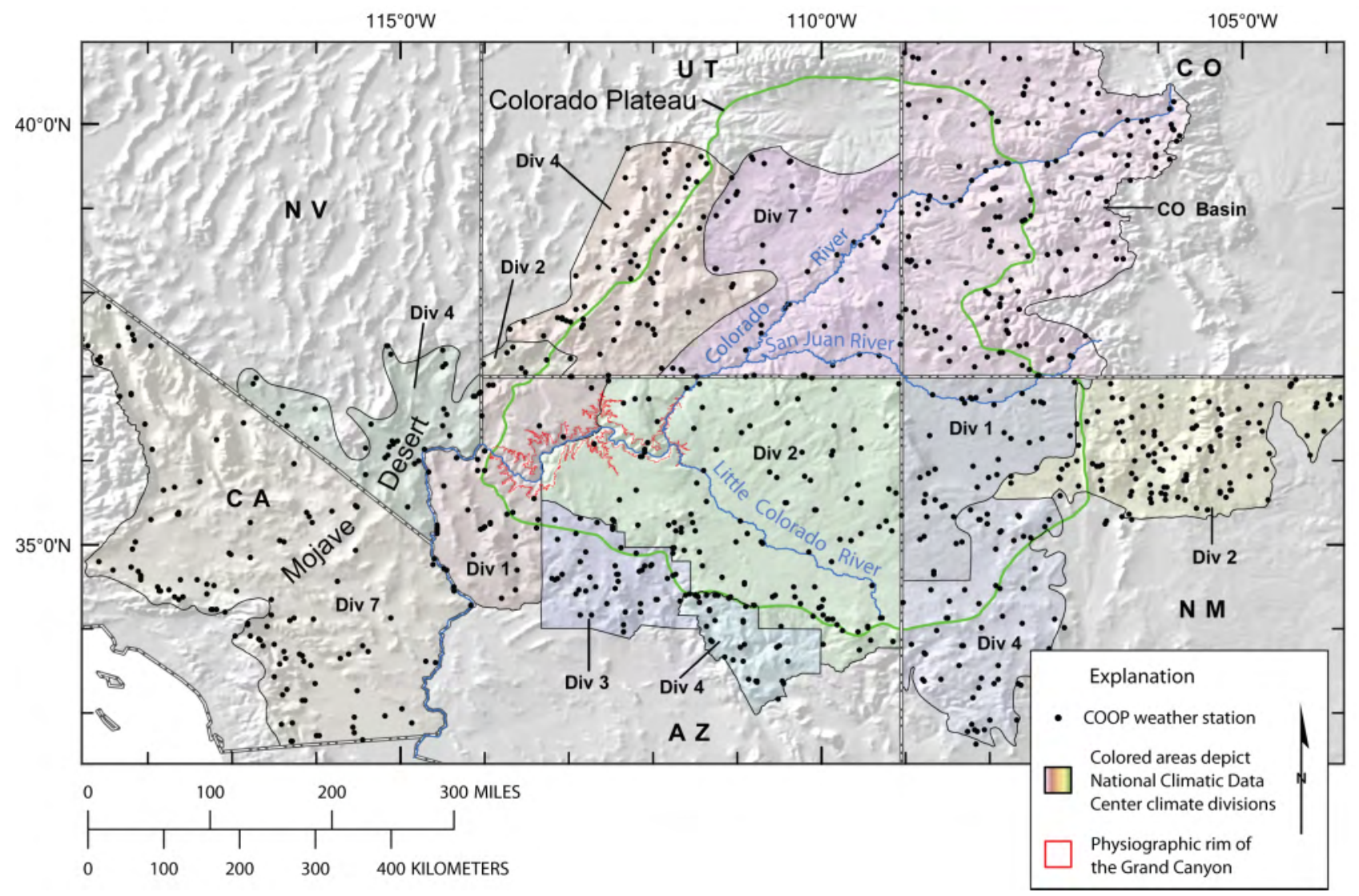

Figure 1. Map showing climate divisions and National Weather Service Cooperative Observer Program (COOP) weather stations in the Grand Canyon, Arizona, region of the Southwest United States. Mojave Desert area includes California Climate Division 7, Arizona Climate Division 1, Nevada Climate Division 4, and Utah Climate Division 2. Colorado Plateau includes Arizona Climate Division 2, Utah Climate Divisions 4 and 7, and New Mexico Divisions 1 and 4. Colorado River Basin (CO Basin) spans the northeast Colorado Plateau and central Rocky Mountains. New Mexico Division 4 is in the southern Rocky Mountains. The Arizona Central highlands include Arizona Climate Divisions 3 and 4. NV, Nevada; CA, California; UT, Utah; AZ, Arizona; CO, Colorado; NM, New Mexico. Div, climate division. (Physiographic rim of Grand Canyon from Billingsley and Hampton 1999.) 


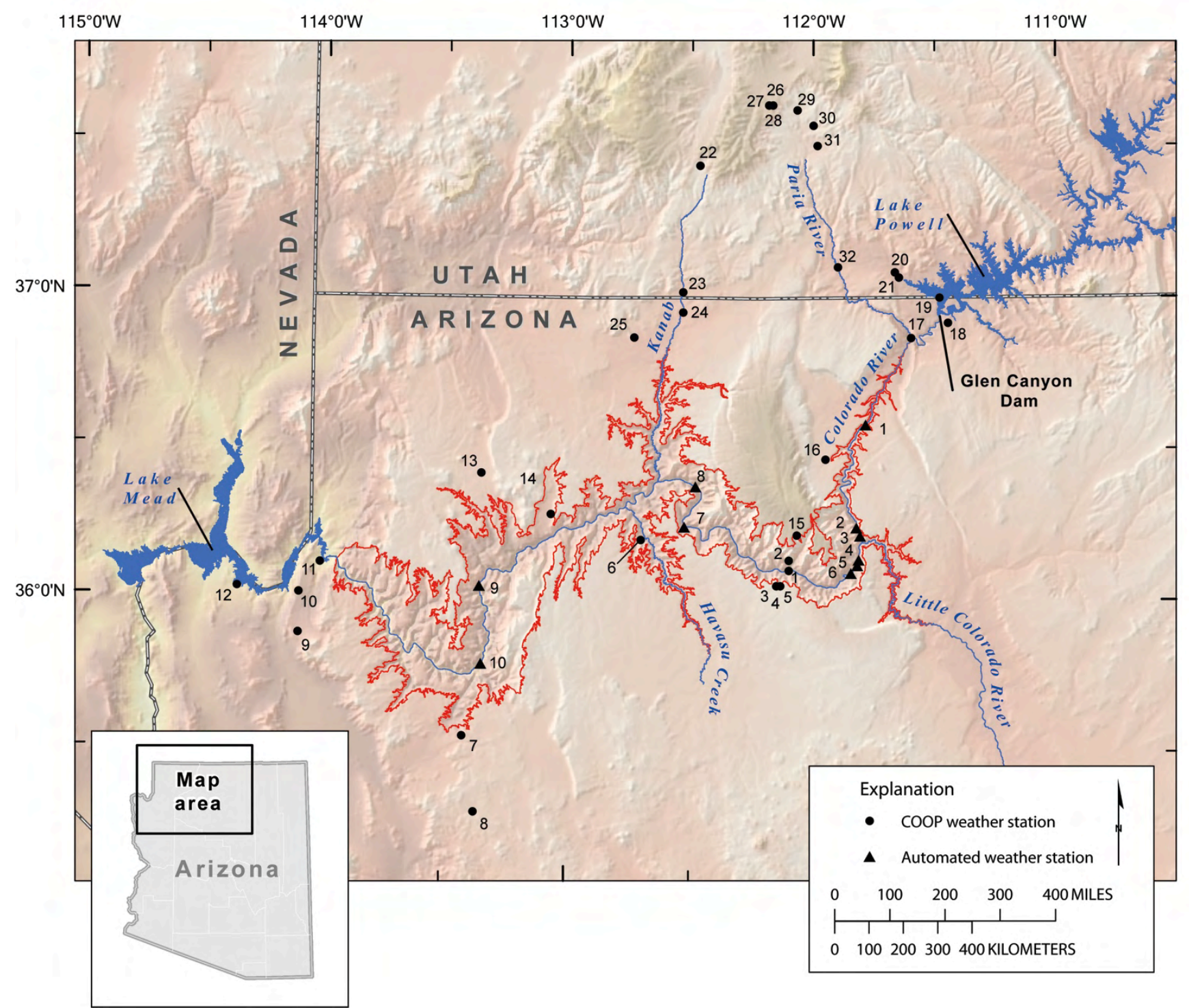

Figure 2. Map showing National Weather Service Cooperative Observer Program (COOP) weather stations (yellow circles) in the local Grand Canyon, Arizona, area and automated weather stations (green triangles) along Colorado River in Grand Canyon. (Physiographic rim of Grand Canyon from Billingsley and Hampton 1999.)

These variations, which are episodes of drought alternating with periods of increased precipitation, affect long-term sediment delivery and erosion of large and small channel systems throughout the region. Results also suggest that a recent multidecadal episode of high average daily precipitation intensity coincides with fluvial erosion and arroyo cutting in the Grand Canyon and elsewhere. This regional association between long-term fluvial activity and precipitation intensity has not been previously recognized.

\section{Previous Studies}

The climatology of precipitation in the Grand Canyon region (GCR) of the American Southwest is reasonably well understood (Sheppard and others, 2002), although the details of 20th and 21st century precipitation variability within Grand Canyon have not been previously investigated. On an annual basis, average precipitation in the GCR ranges from hyperarid (1.9 inches, in.; Roof and Callagan, 2003) 
to arid in the deserts and from arid to semiarid on the high-elevation parts of the Colorado Plateau (5 to 20 in.; Sheppard and others, 2002). Elevation and physiographic barriers are two of the main controls on the amount of precipitation. Precipitation in most of the GCR is biseasonal, except in the western Mojave Desert (fig. 1, California Climate Division 7). Rainfall or snow occurs (depending on elevation) in the cool season from mid-October to mid-April, and rain occurs during the warm season from midJune to October. Late spring is typically dry with little or no precipitation. The characteristics of the dominant wet season vary across the region-warm-season precipitation dominates in southwest New Mexico, whereas cool-season moisture dominates to the west and north.

Cool-season moisture results mainly from extratropical cyclones of the North Pacific Ocean that occur in conjunction with synoptic and planetary-scale tropospheric depressions and with the polar and subtropical jet streams (Pyke, 1972). Rainfall in the deserts and rain or snow on high-elevation areas are widespread and of relatively long duration. Warm-season rainfall results largely from isolated or organized convective thunderstorms. Broadly speaking, this seasonal pattern results from the northerly expansion into the Southwest of the Mexican (North American) Monsoon. The monsoon is a seasonal reversal of atmospheric circulation that transports maritime tropical moisture into the deserts and the Colorado Plateau region (Douglas and others, 1993; Adams and Comrie, 1997). During the latter part of the warm season, in late summer and early fall, tropical cyclones occasionally penetrate northeast into the GCR producing copious, widespread precipitation (Webb and Betancourt, 1992).

Since the late 1980s, the USGS and the National Park Service have been interested in studying the effects of climate and local precipitation events in Grand Canyon. This interest is spurred, in part, by ongoing research concerning the effects of Glen Canyon Dam operations on the Colorado River corridor ecosystem in Glen, Marble, and Grand Canyons. To understand the effects of Glen Canyon Dam operations on the river corridor environment, a better understanding of local climate variability and its effects on the riparian ecosystem is needed. Of particular interest to land and water managers are the relative contributions of climate and dam operations in affecting rates of erosion of sandbars and alluvial terraces, which serve as camp sites for recreational visitors and provide the physical setting for numerous archeological sites (Fairley and others, 1994).

Several previous studies address the effects of climate on Colorado River tributaries in Grand Canyon. These studies treat the effects of climate on floods, debris flows, tributary sediment input, and channel change of Kanab Creek (Webb and others, 1991), Havasu Creek (Melis and others, 1996), Little Colorado River (Hereford, 1984), Paria River (Hereford, 1986; Graf and others, 1991; Topping, 1997; Hereford and Webb, 2003), and smaller ungaged tributaries that mainly head on the rim of Grand Canyon (Webb and others, 2000). However, the aforementioned studies (except Webb and others, 2000) were concerned with the climate of individual basins that drain large areas well outside Grand Canyon. The precipitation history and climate of the Colorado River corridor was not specifically addressed by these studies.

Within the past decade, two separate studies have been initiated within Grand Canyon National Park that focus, in part, on documenting local weather conditions in the Colorado River corridor. The first study, which started in 2003 and ended in 2006, examined the role of sediment supply and eolian sand transport in contributing to the preservation of prehistoric archeological sites located along the Colorado River (Draut and Rubin 2007, 2008). As part of this study, six weather stations consisting of an anemometer (a device used to measure wind speed) and a tipping-bucket rain gage were installed and operated at six locations along the Colorado River corridor between November 2003 and January 2006 (Draut and Rubin, 2005, 2006). Starting in 2007, a new study was initiated by GCMRC that focused on monitoring erosion and deposition at archeological sites and relating measured changes in surface topography to variations in local weather conditions. For this study, new weather stations consisting of tripod-mounted, solar-powered multiparameter ultrasonic Vaisala transmitters were installed at five of the former anemometer stations, plus at four additional locations along the Colorado River in Grand Canyon. Results of this weather monitoring from 2007-2009 are reported in a series of annual reports 
(Draut and others, 2009a,b; 2010). In combination, data collected from the 10 Grand Canyon weather stations between 2003 and 2009 provide high-resolution precipitation data that can be used to evaluate the relation between local rainfall events and rates of erosion of alluvial terraces and associated archeological sites. As discussed below, these data are also well suited for evaluating the relation between inner Grand Canyon precipitation and regional rainfall patterns.

\section{Data}

The analyses discussed in this report rely on two different sources and types of weather data: (1) National Climate Data Center (NCDC) daily precipitation records, spanning the period from 1893 through 2009, and (2) GCMRC 4-minute interval precipitation data, spanning the period from November 2003 through January 2009.

The first dataset consists of daily data collected by the National Climate Data Center (NCDC) from 846 weather stations located in 13 climate divisions (fig. 1). A climate division is an area of broadly homogenous climate with boundaries aligned with drainage basins, major crops (largely irrelevant in the GCR), and (or) county lines (Guttman and Quayle, 1996). The 13 climate divisions are also roughly aligned with the physiographic provinces of the Western United States (Hunt, 1967), as well as with biogeographic provinces of the American Southwest (Lowe and Brown, 1994). NCDC refers to the daily data as the U.S. Daily Surface Data, Summary of the Day Data, cooperative data, or simply COOP (National Weather Service Cooperative Observer Program) data. Data collected at these stations form the core climate network of the United States. Most cooperative observers are State universities, State or Federal agencies, or private individuals whose stations are managed and maintained by the National Weather Service. The COOP data have been reviewed for quality control purposes to remove observer and digitization errors (Kunkel and others, 2005).

Climate division data (arranged by state) used in this study were downloaded from http:/www.ncdc.noaa.gov/oa/climate/stationlocator.html, accessed July 9, 2009. The dataset contains 10.8 million recorded observations from 846 COOP weather stations spanning 117 years from January 1893 through January 2009. The COOP data are difficult to work with, because the number of reporting stations increases through time and the number of stations reporting varies from year to year due to station abandonment or missing observations. Of the 846 stations used in this study, 35 date from 1893, and few of those span the entire 117-year period. Most of the stations have been in operation since 1948, although there are numerous data gaps and stations that operated for only a few years. Potentially, there are 35.8 million observation days in the 117-year period, assuming no missing data and station histories covering 117 years. With 10.8 million observation days, the available data cover 30.1 percent of the potential number of observation days. Despite these limitations, the COOP data are generally recognized as the most authoritative source relating to U.S. climate trends (Wu and others, 2005), and they are the foundation for any comprehensive climate research dealing with precipitation variability.

In addition to the COOP station data, rainfall measured at 10 localities along the Colorado River in Grand Canyon was obtained from Draut and Rubin (2006) and from an additional database managed by the Grand Canyon Monitoring and Research Center, Flagstaff, Arizona (see Draut and others, 2009a, 2009b, and 2010 for annual summary descriptions of the GCMRC data). These high-resolution data cover the period November 2003 through January 2009, although no data were collected in 2006. Precipitation data were collected at the rate of 15 measurements per hour, which is suitable for analysis of precipitation intensity. Precipitation intensity is important as it relates to overland flow and erosion of small ephemeral channels and watersheds of alluvial terraces in Grand Canyon (Pederson and others, 2006). 


\section{Methods}

The downloaded COOP data are in fixed-record length NCDC format. This raw format reduces digital storage space; however, it is essentially unreadable, and for analysis, it must be processed into daily time series. This was done in two steps. First, the individual station data were extracted from the downloaded climate division data. Second, the station data were rewritten into a two-column time series format consisting of the calendar date (MM/DD/YYYY) and the total precipitation of the day expressed in integer form in hundredths of an inch. Non-numeric characters are not allowed in the data field with the exception of " $T$," the symbol for a trace of precipitation. The missing value code is -99 . The beginning and ending dates of the station files were filled in with missing values, if necessary, to begin on the first day (01/01) of the first year and to end on the last day (12/31) of the last year. This data format is suitable for analysis in spreadsheets or with noncommercial software written for that purpose. We are unaware of commercially available software that specifically processes large amounts of daily precipitation data. The station file names terminate with "ppt" to identify the data type. For comparative and cross-checking purposes, the original English measurement units are retained in the data distributed with this report and in the accompanying analyses, except for the data from the automated weather stations, which are given in metric units.

In addition to the data compilation, water-year (October 1 to September 30 of the following year) statistics were calculated for each station with at least 2 years of data. This analysis is packaged with the data in the appendices distributed with this report. The statistics include total water-year precipitation and 15 other parameters. Several of these parameters were chosen to aid interpretation of short- and long-term erosional activity of channels and hillslopes. The parameters relate to minimum (greater than 0) and maximum daily precipitation amounts; various frequencies of daily precipitation exceeding the 90 and 95th percentiles; the corresponding amount of precipitation of these percentiles; the number of days and amount of precipitation greater than or equal to 1 in.; the number of days without precipitation; and the number of single and consecutive days with precipitation exceeding $0.04 \mathrm{in}$. The percentiles were calculated over the period of record of each station. Computer software used in the analysis and to reformat the raw data are described in Hereford (2006). Users of this software should contact the lead author of this report for the latest program revisions.

Following methods described in Hereford and others (2002; 2006), annual or water-year precipitation patterns across the study region were evaluated by comparing average precipitation of the 13 climate divisions (fig. 1). Annual precipitation is expressed as the mean deviation of precipitation from the averages of individual reporting stations of a given climate division. This calculation removes the influence of stations with high precipitation. For a particular station in a given water year, a missing value (-99) was assigned if more than 10 percent of the daily values were missing. The average deviation of total precipitation of the climate divisions is shown graphically in 13 time series grouped into three geographic regions. Similar time series identify multidecadal droughts, wet episodes, and precipitation intensity of Arizona Climate Division 2, and the mean precipitation deviation of stations relating directly to the Grand Canyon part of the study area.

Synchronicity of daily precipitation, for the most part, was analyzed graphically with time series showing day-by-day precipitation and with simple numerical methods that compare the combined and pairwise daily precipitation of four COOP weather stations - one located within the Grand Canyon and three located near the canyon rims. In addition, Spearman's rank correlation coefficients, the number of days with zero precipitation, and the number of times when the four stations reported precipitation simultaneously were calculated. Time series of daily precipitation totals recorded at 10 localities in the river corridor were plotted with precipitation of the COOP station located within the Grand Canyon at Phantom Ranch. This information facilitates comparison of records from the automated stations with those from the long-term COOP reference station. 


\section{Water-Year Precipitation of the 13 Climate Divisions}

Time series of water-year precipitation for each of the 13 climate divisions (fig. 1) were organized into three geographic regions: (1) the southern Colorado Plateau and Central Arizona highlands, encompassing Arizona Climate Divisions 2 through 4, Utah Climate Divisions 4 and 7, and New Mexico Climate Divisions 1 and 4 (fig. 3); (2) Mojave Desert, which includes Arizona Climate Division 1, California Climate Division 7, Nevada Climate Division 4, and Utah Climate Division 2 (fig. 4); and (3) northeast Colorado Plateau and southern Rocky Mountains, encompassing the Colorado River Basin Division in southwestern Colorado and New Mexico Climate Division 2 (fig. 5). The time series (figs. 3-5) cover the 115-year period between October 1, 1893, and September 30, 2008.

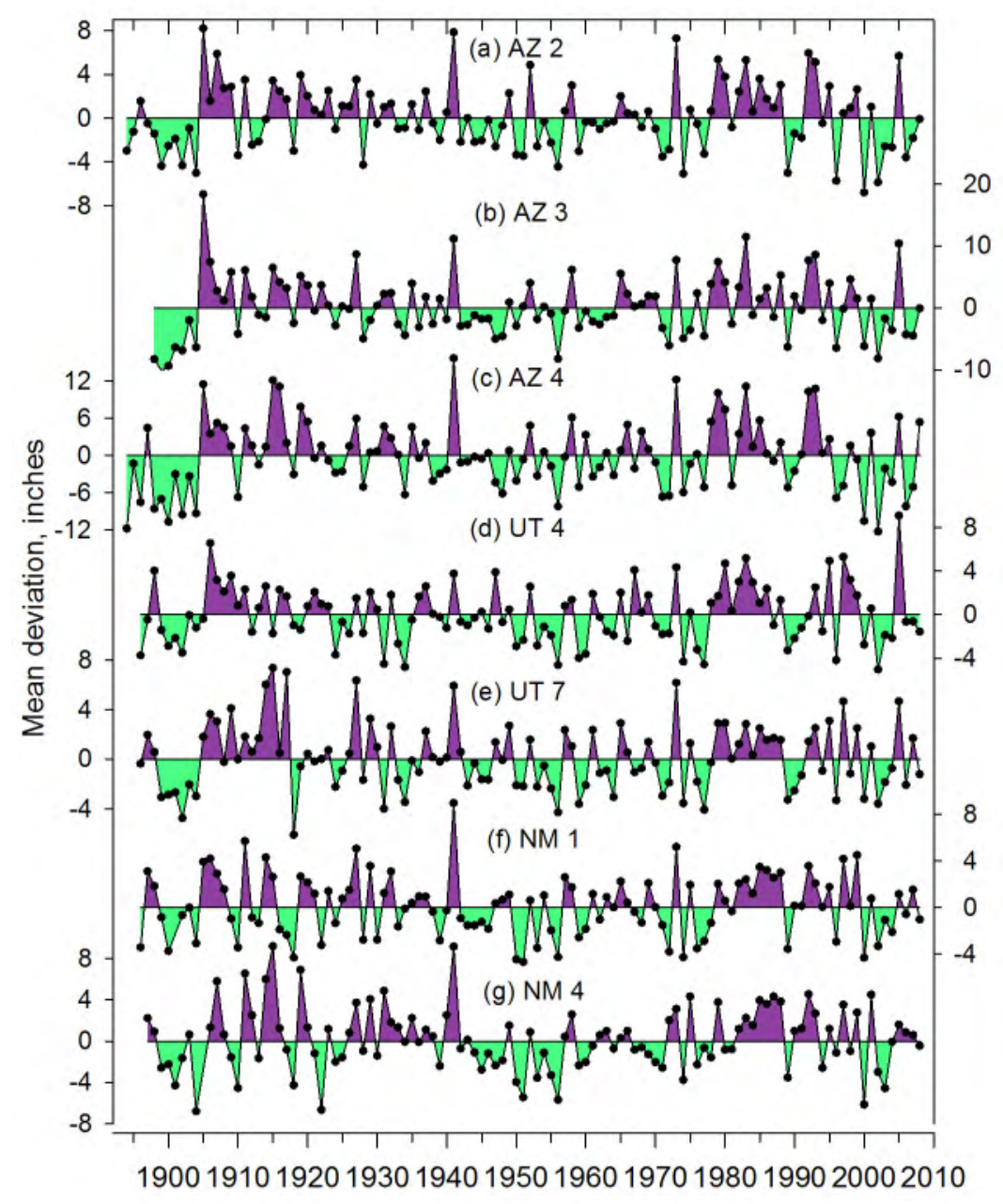

Figure 3. Graph of mean deviation of water-year precipitation from the average total precipitation of individual stations in each of seven climate divisions (a-g; fig. 1) of the Colorado Plateau and Central Arizona highlands. AZ, Arizona; UT, Utah; NM, New Mexico. 


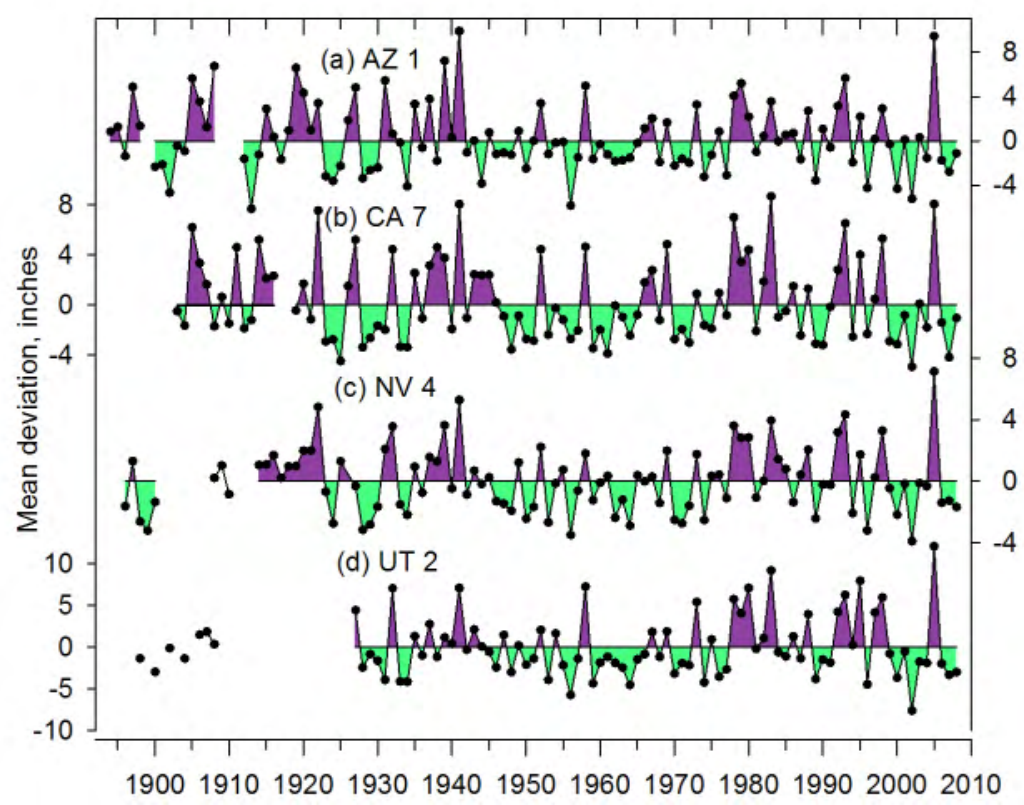

Figure 4. Graph of mean deviation of water-year precipitation from the average total precipitation of individual stations in each of, four climate divisions (a-d; fig. 1) of the Mojave Desert region. AZ, Arizona; CA, California; NV, Nevada; UT, Utah.

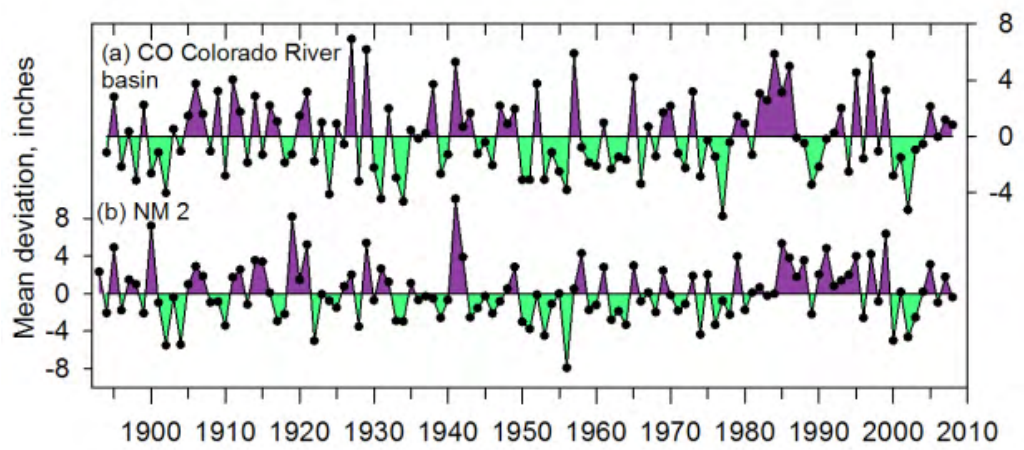

Figure 5. Graph of mean deviation of water-year precipitation from the average total precipitation of individual stations in each of two climate divisions (a-b; fig. 1), of the Colorado River Basin of the northeast Colorado Plateau and New Mexico Climate Division 2 of the southern Rocky Mountains. NM, New Mexico; CO, Colorado.

As previously stated, precipitation is expressed as the division-wide mean of the deviation from the long-term average of each station in the division. These figures show that there are broad similarities of precipitation patterns across the GCR with the possible exception of the Colorado River Basin Division in southwestern Colorado and New Mexico Climate Division 2 (fig. 5). These two divisions include large parts of the southern Rocky Mountains, which may not be representative of the southern Colorado Plateau (Guttman and Quayle, 1996). For the most part, individual years with unusual wet or dry conditions are present in the 13 time series. On an annual basis, 1905, 1927, 1941, 1952, 1957, 1973, 1979, 1980, 1983, 1984, 1992, 1993, 1997, and 2005 were above normal to unusually wet in most climate divisions. Unusually dry years with below normal precipitation were 1904, 1928, 1934, 1956, 1974, 1989, 1996, 2000, 2002, and 2006. 
Although the study area is large (200,000 square miles, $\mathrm{mi}^{2}$; fig. 1 ), water-year precipitation patterns are broadly similar. Based on the 78 unique correlations among the 13 climate divisions, the average correlation among the 13 divisions is $r=0.58 \pm 0.14$ (Pearson correlation coefficient $(r) \pm$ standard deviation). Average correlations within the three geographic groups (figs. 3-5) are $r=0.65 \pm$ 0.13, $0.72 \pm 0.05$, and $0.56 \pm 0.0$, respectively, of the southern Colorado Plateau and Central Arizona highlands, Mojave Desert, and northeast Colorado Plateau and southern Rocky Mountains. All of the correlations are significant at the probability $(P)<0.05$ level.

In the Southwest, the spatial variation of precipitation seasonality and amount is controlled by large-scale atmospheric circulation patterns and local topographic features. This results in the relatively homogenous seasonal precipitation patterns of the Grand Canyon part of the study area (fig. 2), as portrayed by maps of intermonthly precipitation changes and spatial variation of effective moisture in the western United States (Mock, 1996; Shinker and Bartlein, 2010). Seasonal precipitation amounts, moreover, generally differ from those of the Pacific coastal region to the west, the intermountain region to the north and east, and the Great Plains region to the east and southeast. However, major topographic features such as the Mogollon Rim (southern boundary of the Colorado Plateau, fig. 1) and the southern Rocky Mountains (San Juan Mountains) of southwest Colorado affect the relatively homogeneous precipitation distribution. Typically, seasonal changes of precipitation persist through extreme atmospheric circulation patterns, producing unusual maximum or minimum precipitation amounts over large parts of the study area.

\section{Arizona Climate Division 2}

The eastern and central parts of Grand Canyon and the Little Colorado River drainage basin are in Arizona Climate Division 2 (fig. 1; fig.3, (a) AZ 2). Average water-year precipitation of Division 2 is reasonably well correlated $(r=0.76, P<0.05)$ with the average water-year discharge of the Little Colorado River at Cameron, Arizona. The long-term (years to decades) precipitation patterns of Division 2 that are likely relevant to erosional activity in streams, washes, and hillslopes of the GCRincluding large and small tributaries of the Colorado River in Grand Canyon — are variations of total precipitation, as well as variation in the annual frequency of unusual large daily precipitation events.

Multidecadal variations of precipitation are evident in the 115-year precipitation history of Arizona Climate Division 2, as well as in the other climate divisions (figs. 3-5), although, as previously mentioned, they are not well expressed in the Colorado River Basin Division of Colorado and New Mexico Climate Division 2 (fig. 1). Two early droughts or drought-like episodes are apparent in the 20th century (fig. 6). These are an 11-year drought from 1893 to 1904 and the Mid-20th Century Drought (MCD) from the early 1940s to the mid- to late 1970s (Gatewood, 1962; Gatewood and others, 1963; Swetnam and Betancourt, 1998; Hereford and others, 2002). Since about the mid-1990s, the Early-21st Century Drought has affected the region. Precipitation during this drought has been close to or substantially below normal (with the exception of 2005). Indeed, 2000 and 2002 were the driest in 115 years. However, in the midst of this drought, perhaps the driest in 100 years, 2005 was unusually wet, the result of a moderately strong El Niño event. At Flagstaff, Arizona, the winter of 2005 was the third wettest in 57 years, which stands apart from an overall 44-percent decrease of fall, winter, and spring precipitation since the drought began in 1996 (Hereford, 2007).

Two multidecadal wet episodes, the Early 20th Century Pluvial from the mid-1900s to early 1940s and the wet episode of the 1970s to early 1990s, affected precipitation in Arizona Division 2 (fig. 6) and in most of the other climate divisions. The Early 20th Century Pluvial period is thought to be the wettest of the past 1,500 years in the Western United States (Woodhouse and others, 2005). The later wet episode, as previously noted, is particularly noteworthy as it increased overland flow, gullying, and erosion of archeological sites in the river corridor (Hereford and others, 1993). 


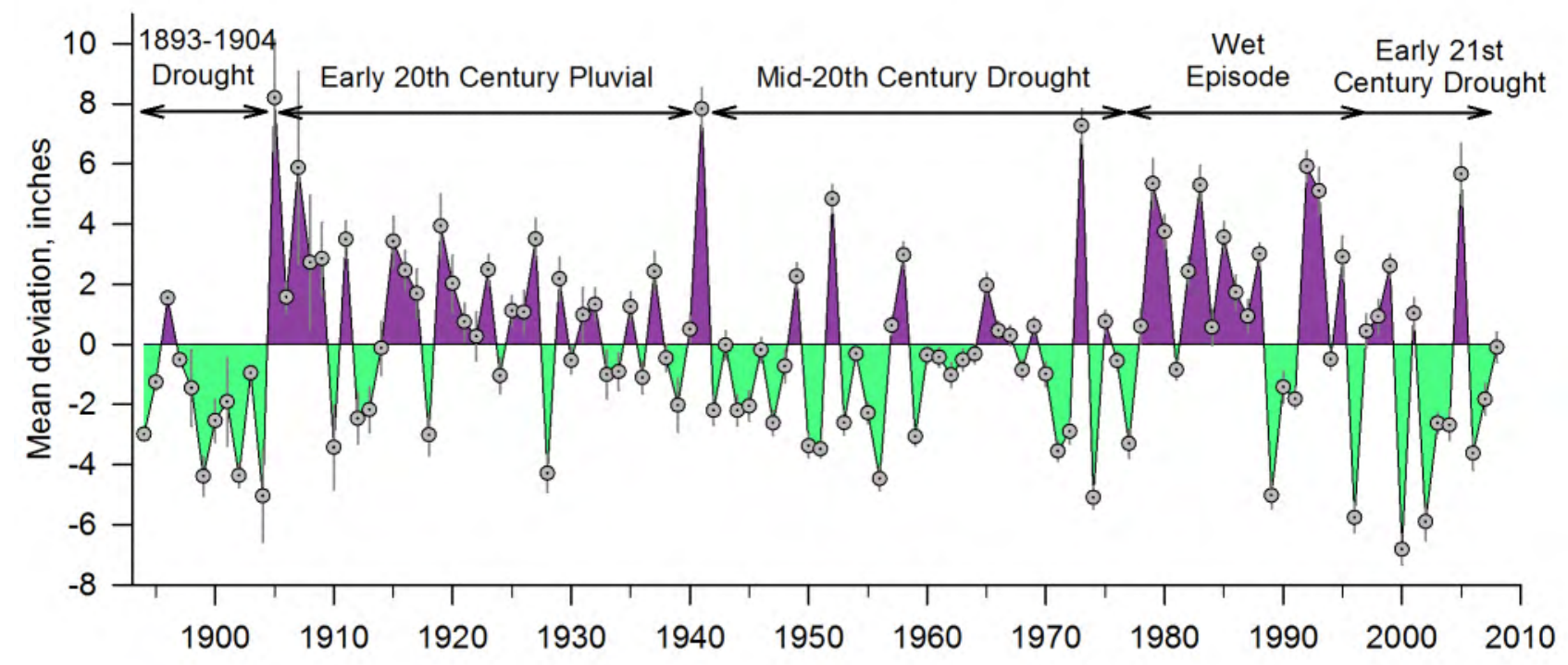

Figure 6. Graph of mean deviation of water-year precipitation showing multidecadal drought and wet episodes for Arizona Climate Division 2. Short vertical line above and below symbol is the standard error of the mean deviation.

Generally, interannual and multidecadal precipitation variability of the southern Colorado Plateau and Mojave Desert is linked spatially and temporally with events in the tropical Pacific and northern Pacific Ocean (Sheppard and others 2002; Hereford and others, 2002, 2003, 2006). Specifically, episodes of unusually wet or dry climate result from interrelated global-scale fluctuations of sea-surface temperature, atmospheric pressure, and atmospheric circulation patterns. These fluctuations operate on two time scales. Short-term, interannual precipitation variability, with a period of 2 to 5 years, is associated with El Niño (possibly wet) and La Niña (usually dry) conditions, collectively termed the El Niño-Southern Oscillation (ENSO); this activity is described by several indices including the Southern Oscillation Index. Large floods in the study area occur with increased frequency during El Niño conditions (Cayan and others, 1999). Multidecadal variability is related to the Pacific Decadal Oscillation (PDO; Mantua and Hare, 2002), which is an ENSO-like indicator of multidecadal climate variability. This long-term variation has a pseudo periodicity of about 35 years in the Mojave Desert region, where it is linked to drought-induced vegetation change (Hereford and others, 2006).

Multidecadal increases of precipitation and the frequency of large precipitation events affect the long-term (years to decades) geomorphic activity of rivers and washes in the region. Large daily precipitation events increase runoff and flood volume, thereby enhancing the erosional effects of precipitation. Figure 7 shows the average number of days annually with high-intensity precipitation events, defined as 24-hour precipitation greater than the 90th percentile of all daily precipitation at a given station. Generally, wet episodes are characterized by increased occurrence of high-intensity precipitation, whereas, the droughts are characterized by a relatively low frequency of intense precipitation. 


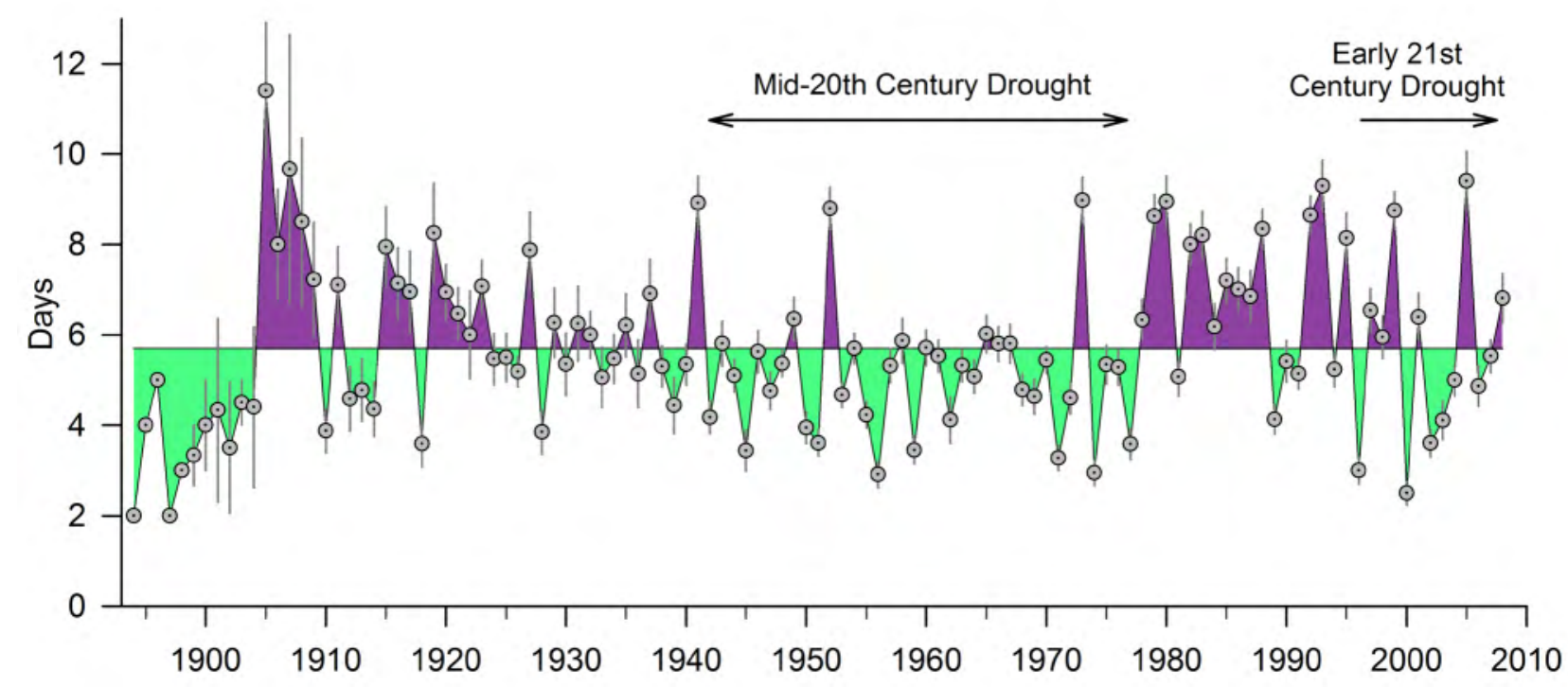

Figure 7. Time series graph showing average number of days annually having precipitation greater than 90th percentile (a measure of daily precipitation intensity) of all precipitation of individual weather stations in Arizona Climate Division 2. Note correspondence between high (low) average number of days with intense daily precipitation and those having above (below) average total precipitation (fig. 5).

These multidecadal climate variations were largely contemporaneous with and presumably a primary cause of geomorphic changes in alluvial channels of the region. During the early 20th century, the Little Colorado River flowed in a wide, flat-floored channel as depicted in numerous ground-based photographs from that period, as well as aerial photography (Hereford, 1984). Indeed, this situation was typical of most rivers and washes of the region, including the Paria and Virgin Rivers of southwest Utah (Hereford, 1984, Hereford and others, 1996) and numerous others in the Southwest (Webb and others, 2007). This channel morphology resulted from frequent large floods that were characteristic of the region until the 1940s (Graf and others, 1991), which in turn were related to the high frequency of heavy precipitation of the early 1900s. Shortly after 1940, channels began to narrow and floodplains developed as vegetation spread into the formerly wide channels. Floodplain development began after a decrease in the frequency of large floods that was largely coincident with the MCD (figs. 6-7). Aggradation continued until the late 1970s when a series of large floods related to the wet episode of the late 20th century incised the same floodplains. Although runoff producing erosion of Holocene terraces in the river corridor of Grand Canyon originates in small basins, typically only a few hectares in size (Hereford and others, 1993), the regional increase in the frequency of intense daily rainfall (fig. 7) is implicated in erosion of these terraces and associated archeological sites in Grand Canyon.

\section{Precipitation Variability in the Grand Canyon Area}

Table 1 identifies 32 COOP weather stations in the local Grand Canyon area (fig. 2). Two of these stations (COOP stations 1 and 2) are near the river in the "heart" of Grand Canyon; 10 are on, below, or near the South Rim; and nine stations are on or near the North Rim (one of the North Rim stations-No. 17, Lees Ferry-is also located near the river but at the upstream end of the canyon); 11 stations are in the Kanab Creek Basin, or in or near Paria River Basin. All together, the 32 stations cover the period January 1893 through January 2009 (fig. 8). Over this period, there are 467,443 recorded 
observation days, which is 33.5 percent of the total possible observation days, assuming no missing data and 117-year station histories. Most of the data gaps are from 1893 to the end of 1949; therefore, information prior to water year 1950 was not used in this analysis.

Table 1. National Weather Service Cooperative Observer Program (COOP) weather stations in or near the Grand Canyon, Arizona.

[Names and abbreviations are those given by the National Climatic Data Center]

\begin{tabular}{ll}
\hline \multicolumn{1}{c}{ Inner Canyon Stations } \\
\hline 1. & Inner Canyon USGS \\
2. & Phantom Rch \\
\hline & \multicolumn{1}{c}{ Near Rim Stations } \\
\hline & \multicolumn{1}{c}{ South Rim } \\
3. & Grand Canyon Hq \\
4. & Grand Canyon NP \\
5. & Grand Canyon NP 2 \\
6. & Supai \\
7. & Peach Springs \\
8. & Diamond M Rch \\
9. & Pierce Ferry 17 SSW \\
10. & Meadview 1SE \\
11. & Pierce Ferry \\
12. & Temple Bar \\
& \\
13. & Mt Trumbull \\
14. & Tuweep \\
15. & Bright Angel RS \\
16. & Buffalo Rch \\
17. & Lees Ferry \\
18. & Page \\
19. & Wahweap \\
20. & Glen Canyon City \\
21. & Big Water \\
\hline & $\quad$ Stations in Kanab Creek \\
\hline 22. & Alton in or near Paria River Basin \\
23. & Kanab \\
24. & Fredonia \\
25. & Pipe Springs Natl Mon \\
26. & Bryce Canyon Nat'l Prk \\
27. & Bryce Cnyn Nat'l Prk \\
28. & Bryce Canyon NP Hqrs \\
29. & Tropic \\
30. & Henrieville \\
31. & Kodachrome Basin Park \\
32. & Paria RS \\
\hline
\end{tabular}




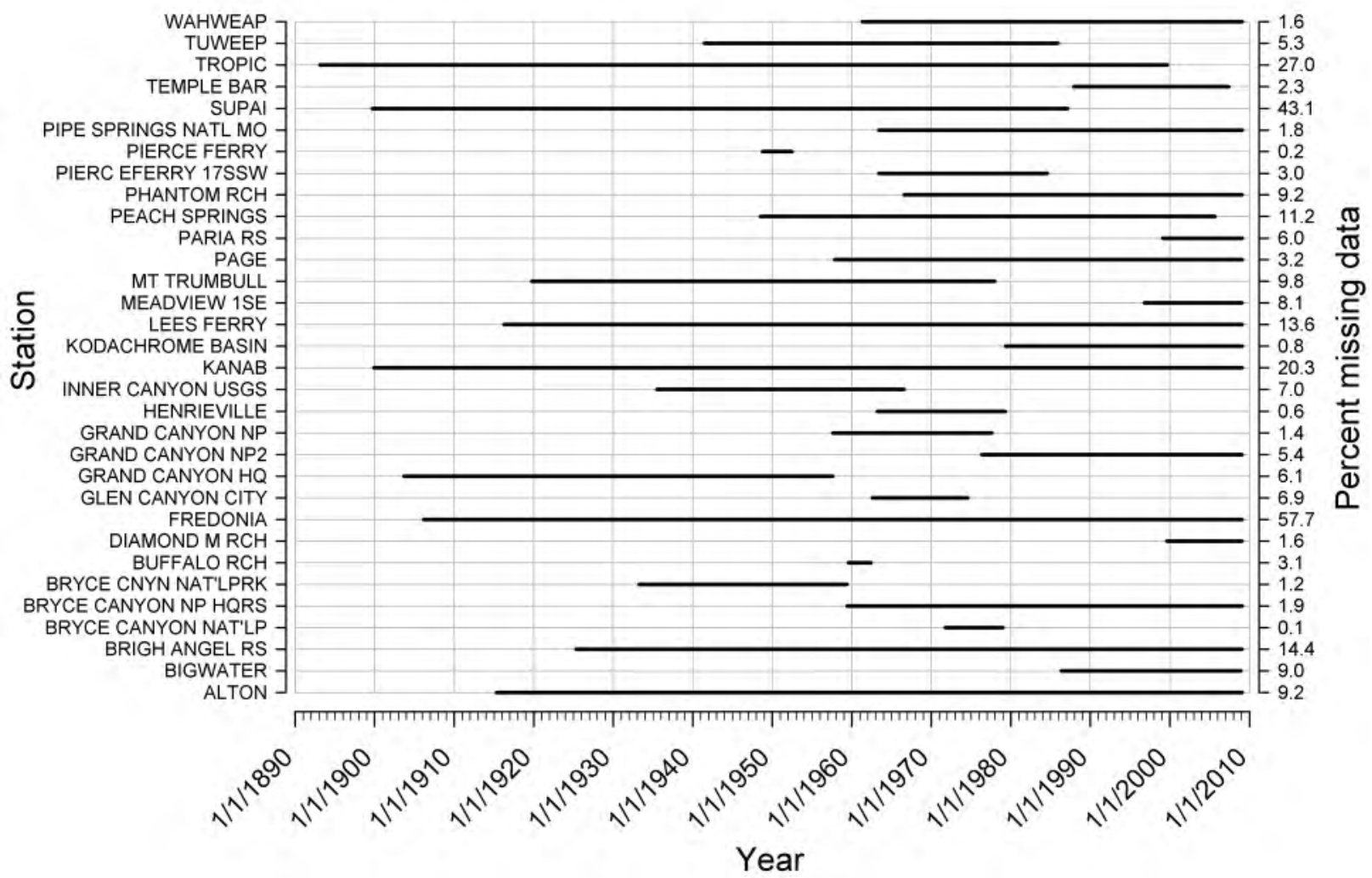

Figure 8. Graph showing name, period of record (horizontal lines), and percent missing daily entries of National Weather Service Cooperative Observer Program (COOP) weather stations in the local Grand Canyon area. Names and abbreviations are those given by the National Climatic Data Center. Year format is January 1 , YEAR.

The temporal variations of water-year precipitation (fig. 9) are similar to those evident in figures 3 to 6. Most of the Grand Canyon area stations (table 1) were unusually wet in 1952, 1958, 1973, 1979, $1980,1983,1992,1993,1997$, and 2005. Most of them were unusually dry in 1956, 1974, 1977, 1996, 2000, and 2002. This is essentially the same pattern of wet and dry years evident in 11 of the 13 climate divisions for the same period of record. 


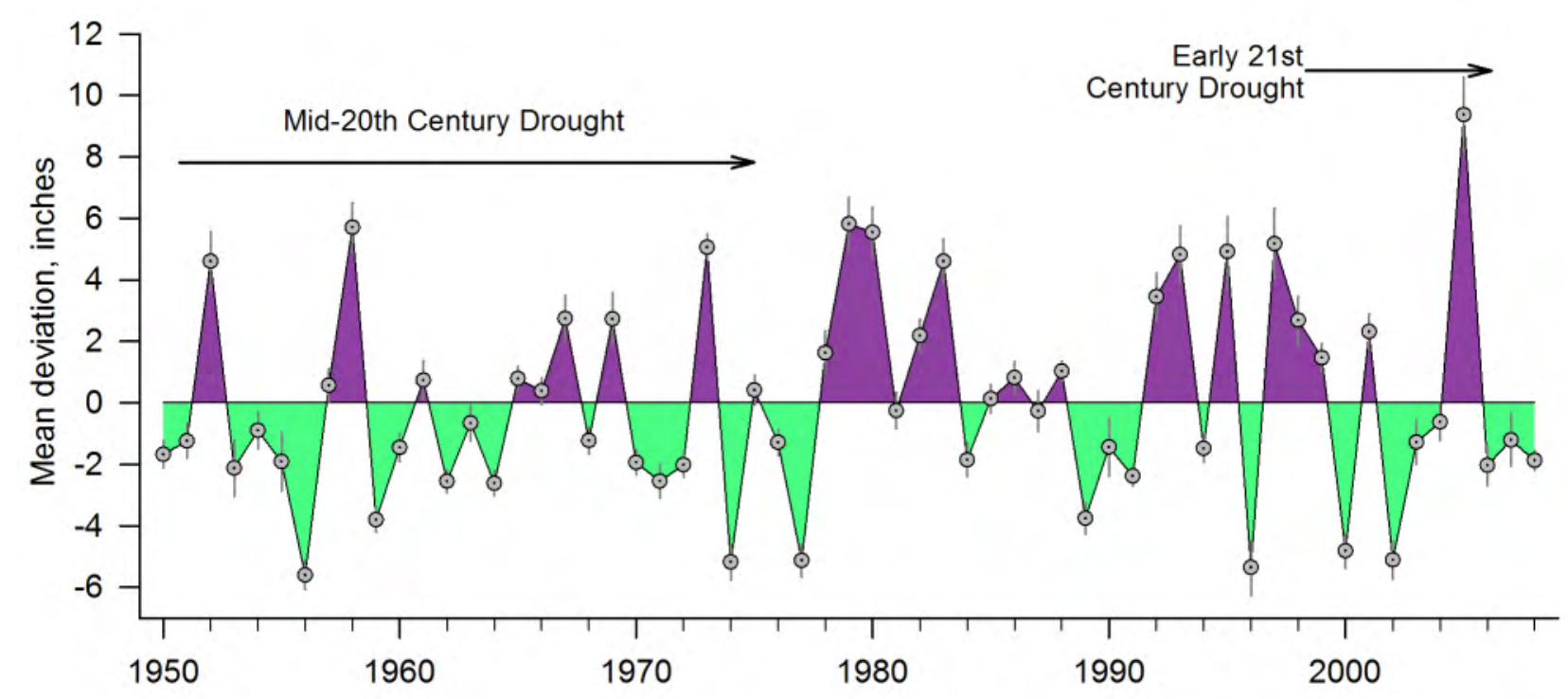

Figure 9. Graph of mean deviation of water-year precipitation from 1950 to 2008 for Grand Canyon, Arizona, area National Weather Service Cooperative Observer Program (COOP) weather stations (table 1; fig. 2).

On a longer time scale, the MCD is evident as a period of mostly below average precipitation that was already underway by water year 1950 and ended in 1977. The drought-like conditions during this period were interrupted by wet years 1952, 1958, and 1973 that were coincident with specific El Niño events (Hereford and others, 2002). The period 1978-1995 was above normal for the most part, except for 1989-1991, which was unusually dry, as was the case elsewhere in the Southwest.

\section{Historic Daily Precipitation in Grand Canyon and on Nearby Rims}

The preceding analysis results suggest that annual precipitation patterns are generally similar throughout most of the GCR (figs. 1 and 3-5), as well as within the Grand Canyon area (figs. 2 and 9). The purpose of this section is to discuss concordance of daily rainfall of the inner canyon with precipitation from several stations located nearby on the canyon rims.

Two weather stations are located in Grand Canyon on Bright Angel Creek, three stations are located nearby on the North and South Rims, and another station at relatively low elevation is located near the river at Lees Ferry (table 1; fig. 2 COOP nos. 1-5, 15, and 17, respectively). A 19-year record spanning 1990 through 2008 consisting of 7,305 observation days from the Phantom Ranch, Bright Angel Ranger Station, Grand Canyon National Park 2, and Lees Ferry stations was analyzed. Only 19 years of the record were used to facilitate comparison of the plots. In addition, the level of concordance, or synchronicity, among the stations and comparison of concordance between Phantom Ranch and the other stations were calculated.

The daily time series of each of the four stations is shown in figure 10, which shows an apparent high degree of concordance of precipitation among the four stations. This is well illustrated by 1992, 1993, and 2005, which were unusually wet years, particularly in Arizona Climate Division 2 (fig. 6). Overall, the largest variation appears to be the amount of precipitation. Otherwise, the daily precipitation episodes appear to occur mostly at the same time, which in most cases corresponds with the winter and summer moist seasons. 


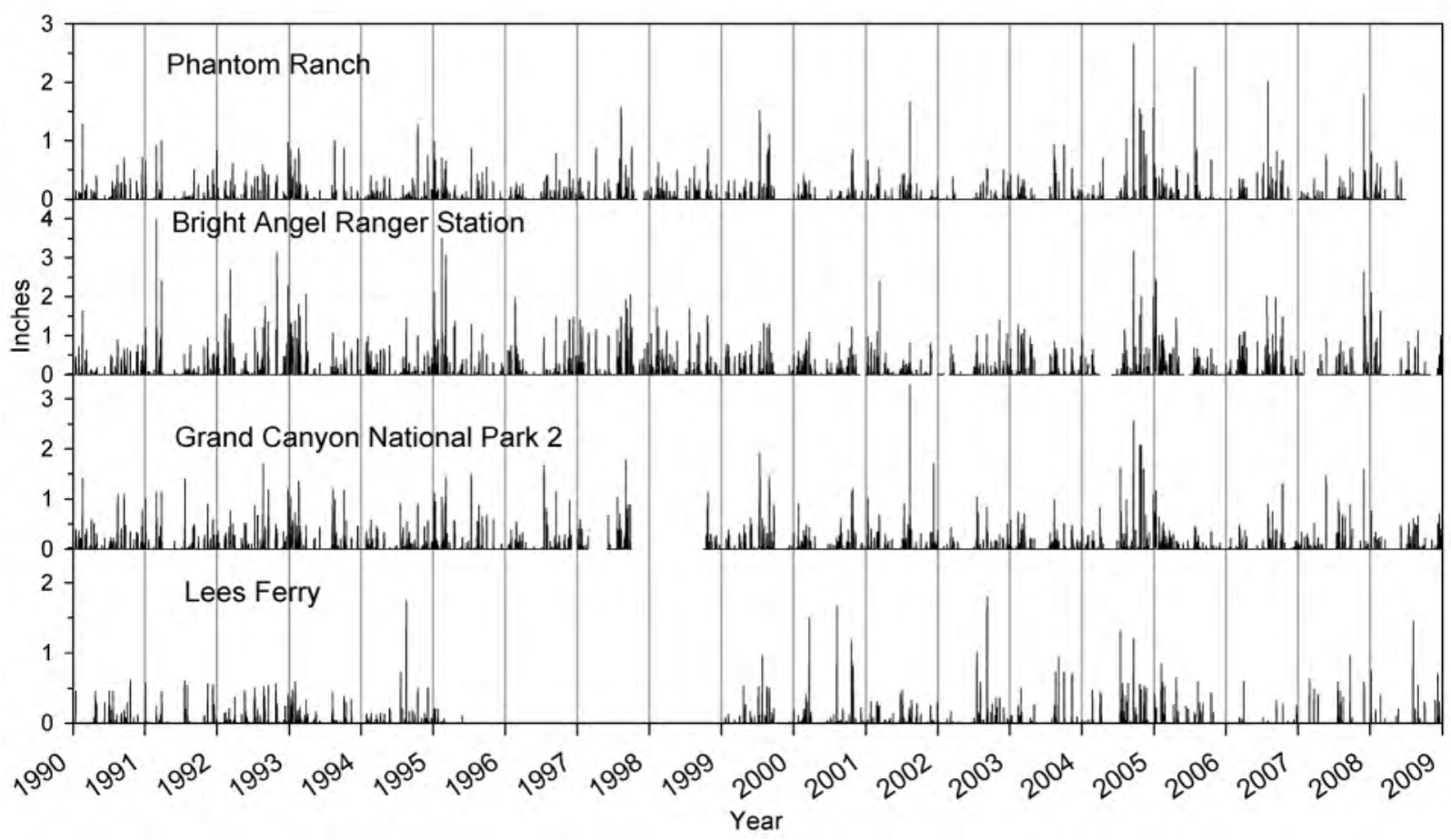

Figure 10. Graph showing four daily precipitation time series, 1990 to 2009, of National Weather Service Cooperative Observer Program (COOP) weather stations in Grand Canyon, Arizona, and on the canyon's North and South Rims (table 1; fig. 2). Breaks in the x-axis are missing data and horizontal lines correspond to zero precipitation. An effective way to visualize alignment of the precipitation patterns is to view the plot from the base of the graph at a low angle.

Correlation coefficients were calculated from the full record of the four stations over the period 1996 through 2008. The relevant correlations are Phantom Ranch paired with Bright Angel Ranger Station, Grand Canyon National Park 2, and Lees Ferry; the correlations are 0.74, 0.76, and 0.51, respectively. The correlations are significant at the $P<0.05$ level, which reflects the large number of observations for each pair. However, the coefficients are probably somewhat inflated as they relate to both days with precipitation and days with no precipitation, which are numerous.

Because only four stations are involved, it is rather straightforward to calculate the number of times that precipitation occurred simultaneously among the four stations and to compare precipitation occurrences between Phantom Ranch and the other stations (table 2). The only restriction is that all of the stations report on a given date. When all four stations reported simultaneously, there were 5,684 dates with no precipitation at each station, 3,341 cases of precipitation at one to three of the stations, and 681 cases of precipitation at all four stations. Thus, of all daily instances of precipitation, only 20.4 percent occurred simultaneously at four stations, although it is likely that a 2- or 3-day moving window would increase synchronicity among the four stations. The pairwise comparisons are 55.6, 54.2, and 34.2 percent simultaneous precipitation occurrences, respectively. Although these values are not very high, it seems apparent that it is not unusual for widespread precipitation to occur on or about the same date. This seems reasonable, because precipitation originates from weather systems that are much larger than the local Grand Canyon area. 
Table 2. Comparison of daily simultaneous precipitation occurrences for four Grand Canyon, Arizona, National Weather Service Cooperative Observer Program (COOP) weather stations.

[Shown are when all stations reported no precipitation or recorded precipitation, percent of simultaneous precipitation occurrences of all stations, and three pair-wise comparisons of Phantom Ranch (PR; elevation 772 meters) with rim stations Bright Angel Ranger Station (BARS; elevation 2,562 meters), Grand Canyon National Park 2 (GCNP 2; elevation 2,069 meters), and Lees Ferry (LF; 1071 elevation meters), 1966 through 2008. km, kilometers]

\begin{tabular}{lccccc}
\hline Comparison & $\begin{array}{c}\text { All stations } \\
\text { reported }\end{array}$ & $\begin{array}{c}\text { Simultaneous } \\
\text { occurrences of zero } \\
\text { precipitation }\end{array}$ & $\begin{array}{c}\text { Simultaneous } \\
\text { occurrences of } \\
\text { precipitation }\end{array}$ & $\begin{array}{c}\text { Percent } \\
\text { simultaneous } \\
\text { precipitation }\end{array}$ & $\begin{array}{c}\text { Distance from } \\
\text { PR (km) }\end{array}$ \\
\hline All stations & 9,025 & 5,684 & 681 & 20.4 & - \\
PR/BARS & 12,745 & 8,850 & 2,165 & 55.6 & 54.2 \\
PR/GCNP 2 & 10,956 & 8,446 & 1,361 & 34.2 & 10.5 \\
PR/LF & 12,262 & 9,866 & 819 & & 93.2 \\
\hline
\end{tabular}

\section{Daily Precipitation Along the Colorado River}

Automated weather stations collecting high-temporal-resolution precipitation data operated along the river corridor at 10 archeologically sensitive localities from 2003 through 2008 (fig. 2; Draut and others, 2009a,b). Daily time series from the 10 stations and the Phantom Ranch COOP station (no. 2 in fig. 2) are shown in figure 11 arranged from top to bottom in the downstream direction, with the distance given between stations measured as a straight line. It is apparent that the automated data are fragmentary when compared with Phantom Ranch, which points out the difficulties of maintaining automated operations in the remote and harsh physical environment of the river corridor (Draut and others, 2009a). 


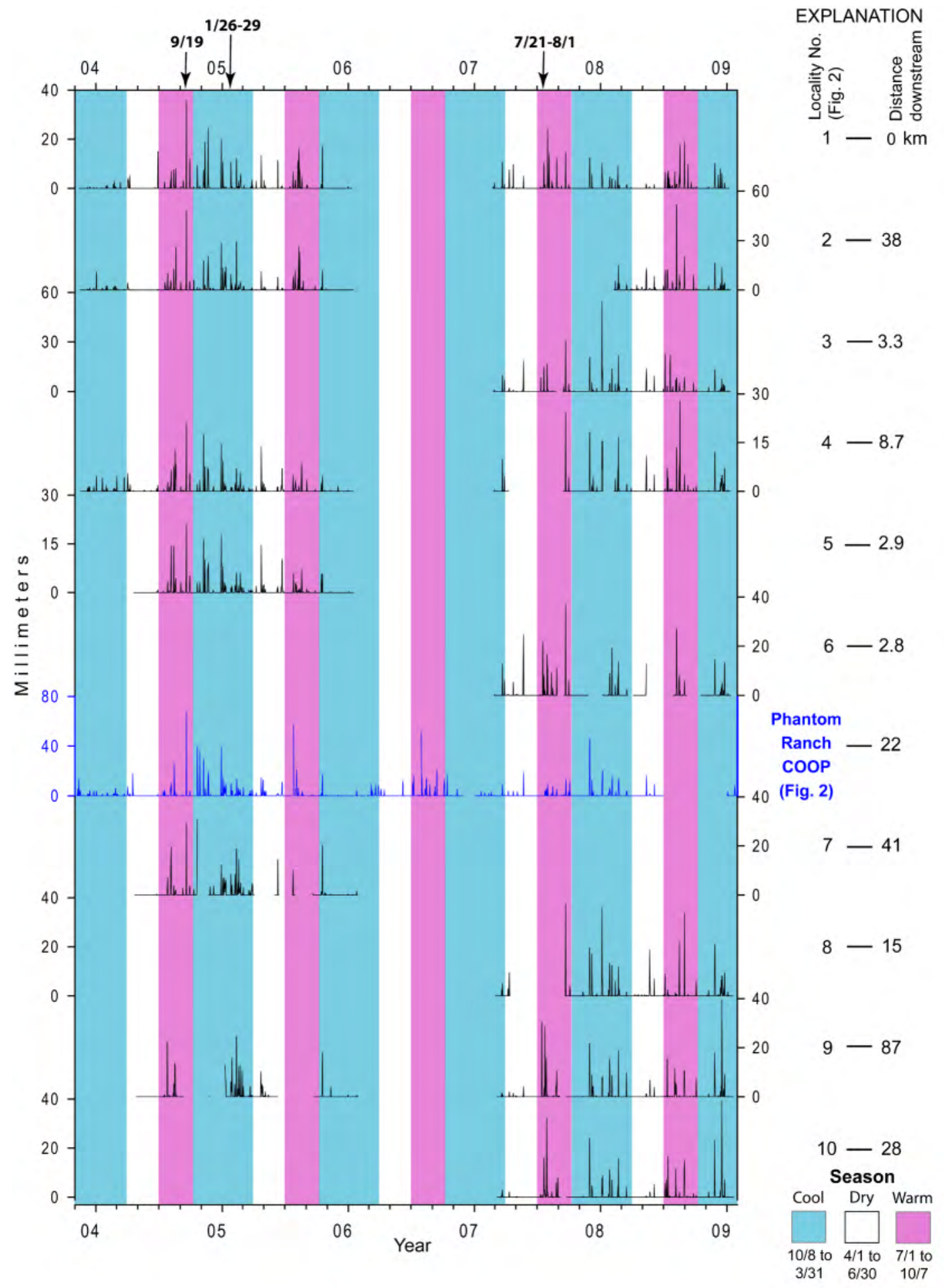

Figure 11. Graph showing daily time series, November 2003 through December 2009, of automated weather stations along the Colorado River corridor in Grand Canyon, Arizona, at 10 archeologically sensitive localities and Phantom Ranch COOP station (table 1). Breaks in the $\mathrm{x}$-axis are missing data and horizontal lines correspond to zero precipitation. Three widespread wet episodes are identified on upper $x$-axis. Colored patterns show three precipitation seasons derived from the annual precipitation cycle of Phantom Ranch during the period August 1, 1966, through January 31,2009. The annual precipitation cycle is the average daily rainfall of each day of the calendar year (366 days) computed over the period of record. 
Despite the fragmentary record, precipitation patterns among the 10 localities and with Phantom Ranch appear roughly similar. For example, on September 19, 2004, rain fell at all six reporting stations extending downstream from locality one to seven (figs. 2 and 11), a distance of 119 kilometers (km). January 26 to 29, 2005, was another wet spell with seven stations reporting from localities one to nine. Rain did not occur on the 28th at any locality, whereas precipitation occurred at every locality during the other 3 days. July 21 to August 1 was a prominent wet spell in the warm season of 2007. With the exception of the 25th, when it did not rain at seven localities, rain of widely varying amounts fell on 82 percent of the remaining 66 observation days extending $249 \mathrm{~km}$ from localities one to 10.

Further examination of the plots (fig. 11) shows that daily simultaneous precipitation at several to many of the stations was not unusual. The most conspicuous of these events occurred in late November and December 2004; mid-February, late July, and early August 2005; September 22, 2007; and early January, mid-August, and late November 2008.

\section{Discussion}

The weather data analyzed for this study demonstrates broad synchroneity in precipitation patterns within the study region. This is evident in terms of short-term events (days to annually), as well as multidecadal time scales. Multidecadal variability during the past 117 years has implications for resource management in the Grand Canyon, because precipitation strongly affects the recovery rates from natural and human disturbances. For example, the results of studies of floral and faunal population dynamics, as well as gullying of river terraces, are dependent on the prevailing climate. Inferences and projections based on such studies may not be valid or may need adjustment or reappraisal if they are applied to a different climate regime such as the ongoing Early 21st Century Drought. Moreover, the exploratory analysis undertaken herein suggests that the regional climate information may serve as a proxy for locally derived monitoring data when assessing effects of climate and short-term weather events at specific sites in the Grand Canyon, especially in areas where weather-monitoring stations are lacking.

The results of our analysis lend support to previous conclusions that the late-20th century wet episode with its increased precipitation intensity coupled with the effects of regulated streamflow accelerated erosion of archeological sites in Grand Canyon (Hereford and others, 1993; Fairley 2003, 2005). The winter of 1993, for example, was unusually wet throughout the region (figs. 3-4, 6 and 9; House, 1993), the result of vigorous and lengthy ENSO activity (Trenberth and Hoar, 1996) —headcut erosion of alluvial terraces and associated archeological sites was observed in spring 1993 following intense winter storms (fig. 12). Much of this erosion involved gully entrenchment and widening that continues, albeit less vigorously, into the Early 21st Century Drought (Hazel and others, 2008). Even in these relatively dry conditions, gullying has proven difficult to control (Pederson and others, 2006). 


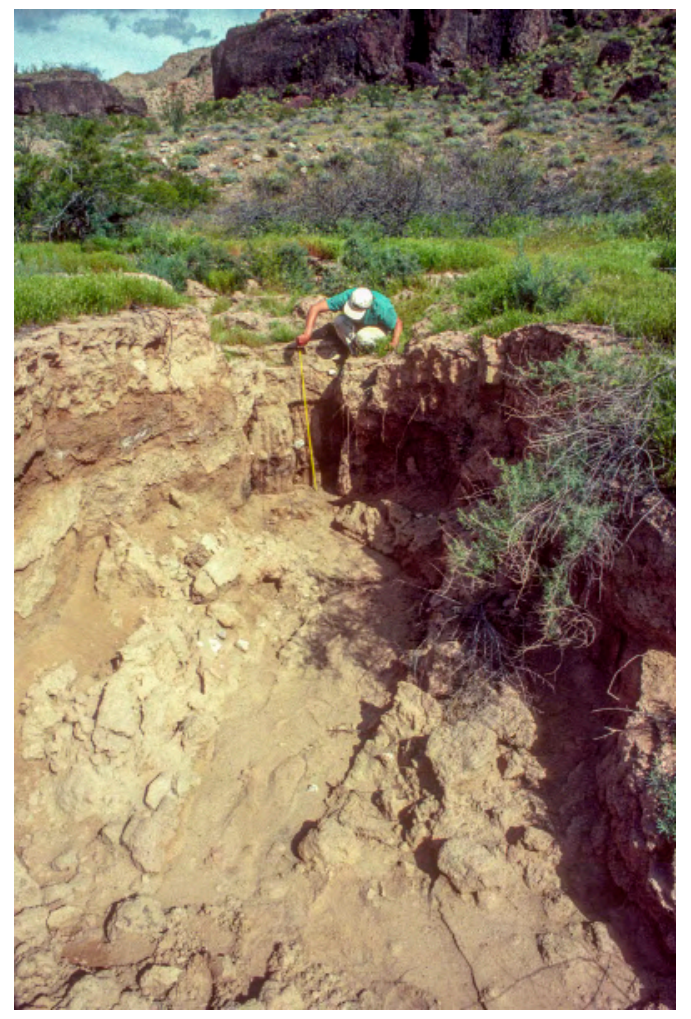

Figure 12. Photograph showing headcut migration and gullying active shortly before March 1993 during the unusually wet winter of 1992-1993, upper Granite Park area of the western Grand Canyon, Arizona (U.S. Geological Survey photograph by R. Hereford).

The automated weather station records from inner Grand Canyon are short, contain numerous gaps, and new instruments were installed in 2007; nonetheless it is possible to calculate precipitation statistics for the river corridor such as intensity and average daily, monthly, and perhaps annual precipitation. Additional statistical analysis of this information is needed to quantitatively relate river corridor precipitation patterns to climate of the larger region and to evaluate spatial variability. More importantly, precipitation intensity measured by the high-resolution automated weather stations can be linked with measurements of erosion in the river corridor. This information could then be used to trigger future monitoring and remedial efforts. Furthermore, because total daily precipitation is a function of intensity, the long-term daily precipitation data can be used in the future to infer past erosional events from the historical record.

Because the period of record is short and the data is spotty, it is uncertain to what degree precipitation measurements from one locality can be extrapolated to other localities in the Canyon and to regional climate. Moreover, we did not attempt to analyze the extent to which precipitation amounts vary spatially among the localities. A more rigorous analysis is needed to determine how the data from the inner canyon stations correlate with regional climate. Further work is also needed to identify how precipitation intensities and patterns are associated with site erosion, to evaluate the long-term erosional potential of the sites, and to recognize past erosional episodes using the daily historic records. With the high-resolution data, it may be possible to gain additional information from the historical daily data, particularly the statistical relations between total daily rainfall and 4-minute precipitation intensities. 


\section{Summary and Conclusions}

The first objective of this project was to compile for dissemination a historical daily precipitation dataset for the GCR that is suitable for climate research centered on the Grand Canyon and the larger southern Colorado Plateau (fig. 1). These data, and associated analyses, are contained in the dataset provided with this report. The data contain information useful in the physical and biological sciences, and may also be useful for understanding erosion of terrace-based archeological sites, because the data relates to short- (days) and long-term (months to decades) precipitation variability having the potential to affect runoff, sediment transport, and ecosystem processes. The second objective was an exploratory analysis of the temporal correlation of precipitation patterns on an annual to daily basis. The purpose was to scale precipitation variability down from regional to local (the inner Grand Canyon) and temporally from annual to daily. This exploratory analysis points out several possibilities for additional research on climate variation in and around the Grand Canyon.

The primary dataset consists of 10.8 million observations spanning January 1893 through January 2009 from 846 weather stations located in the six states and 13 climate divisions surrounding the Grand Canyon (fig. 1). The raw data processed in this report are maintained by the National Climate Data Center, Asheville, North Carolina. The data were collected under the auspices of the ongoing National Weather Service's National Cooperative Observer Program, which is a network of more than 19,000 weather stations (known as COOP stations) in the United States.

In addition to processing the data for distribution, water-year precipitation totals and other statistical parameters were calculated for each weather station with more than 2 years of observations. Division-wide total precipitation, expressed as the average deviation from individual station means of a climate division, is shown graphically in time series (figs. 3-5 and 9). These plots suggest that precipitation of the larger GCR, as well as the local Grand Canyon area, has varied substantially over the 117-year record. Three multiyear to multidecadal droughts have affected the region during the period of record: (1) drought from 1893 to 1904, (2) the Mid-20th Century Drought from the early 1940s to 1970s, and (3) the ongoing Early 21st Century Drought beginning in the mid- to late 1990s (fig. 6). Two episodes of relatively wet climate occur between the first and second drought and the second and third drought. The recent wet episode of the late 1970s to mid-1990s caused gully erosion of Holocene terraces and archeological sites in the Grand Canyon (fig. 12). During wet episodes, precipitation intensity (fig. 7) increased, further enhancing runoff and fluvial erosion across a wide range of spatial scales.

An exploratory study of precipitation measurements collected by automated weather stations at 10 archeologically sensitive localities along the Colorado River in Grand Canyon (figs. 2, 11) was undertaken to examine the correlation of precipitation events among the localities and for correlation with a long-term COOP station in the inner canyon. Examination of the plotted time series suggests that on a daily basis there is considerable variation in the amount of precipitation, although the occurrence of precipitation is broadly synchronous at most of the reporting stations (figs. 10-11) regardless of season. Daily and seasonal rainfall patterns apparent in these data are evidently not random, although at times precipitation amounts vary substantially across the canyon. The results of this data exploration leads to the conclusion that additional analysis of historical and contemporary weather data from the Grand Canyon region is appropriate and necessary to more fully explore and quantify the relation between local and regional precipitation patterns, and specifically the variation in daily amounts and intensity of rainfall, within the Grand Canyon region. 


\section{References}

Adams, D.K., and Comrie, A.C., 1997, The North American monsoon: Bulletin of the American Meteorological Society, v. 78, p. 2197-2213.

Billingsley, G.H., and Hampton, H.M., 1999, Physiographic rim of the Grand Canyon, Arizona-A digital data base: U.S. Geological Survey Open-File Report 99-30, scale 1:100,000, with pamphlet.

Cayan, D.R., Redmond, K.T., and Riddle, L.G., 1999, ENSO and hydrologic extremes in the western United States: Journal of Climate, v. 12, p. 2881-2893.

Douglas, M.V., Maddox, R.A., Howard, K., and Reyes, S., 1993, The Mexican monsoon: Journal of Climate, v. 6, p. 2882-2893.

Draut, A.E., and Rubin, D.M., 2005, Measurements of wind, aeolian sand transport, and precipitation in the Colorado River corridor, Grand Canyon, Arizona-November 2003 to December 2004: U.S. Geological Survey Open-File Report 2005-1309, 70 p., available at http://pubs.usgs.gov/of/2005/1309/.

Draut, A.E., and Rubin, D.M., 2006, Measurements of wind, aeolian sand transport, and precipitation in the Colorado River corridor, Grand Canyon, Arizona-January 2005 to January 2006: U.S. Geological Survey Open-File Report 2006-1188, 88 p., available at http://pubs.usgs.gov/of/2006/1188/.

Draut, A.E., and Rubin, D.M., 2007, The role of aeolian sediment in the preservation of archaeological sites in the Colorado River corridor, Grand Canyon, Arizona-Final report on research activities 2003-2006: U.S. Geological Survey Open-File Report 2007-1001, 141 p., available at http://pubs.usgs.gov/of/2007/1001/.

Draut, A.E., and Rubin, D.M., 2008, The role of eolian sediment in the preservation of archeologic sites along the Colorado River corridor in Grand Canyon National Park, Arizona: U.S. Geological Survey Professional Paper 1756, 71 p., available at http://pubs.usgs.gov/pp/1756/.

Draut, A.E., Andrews, T., Fairley, H.C., and Brown, C.R., 2009a, 2007 weather and aeolian sandtransport data from the Colorado River corridor, Grand Canyon, Arizona: U.S. Geological Survey Open-File Report 2009-1098, 110 p., available at http://pubs.usgs.gov/of/2009/1098/.

Draut, A.E., Sondossi, H.A., Hazel, J.E., Jr., Andrews, A., Fairley, H.C., Brown, C.R., and Vanaman, K.M., 2009b, 2008 weather and aeolian sand-transport data from the Colorado River corridor, Grand Canyon, Arizona: U.S. Geological Survey Open-File Report 2009-1190, 98 p., available at http://pubs.usgs.gov/of/2009/1190/.

Draut, A.E., Sondossi, H.A., Dealy, T.P., Hazel, J.E., Jr., Fairley, H.C., and Brown, C.R., 2010, 2009 weather and aeolian sand-transport data from the Colorado River corridor, Grand Canyon, Arizona: U.S. Geological Survey Open-File Report 2010-1166, 98 p., available at http://pubs.usgs.gov/of/2010/1166/.

Fairley, H.C., Bungart, P.W., Coder, C.M., Huffman, J., Samples, T.L., and Balsom, J.R., 1994, The Grand Canyon river corridor survey project-Archaeological survey along the Colorado River between Glen Canyon Dam and Separation Canyon: Unpublished report prepared in cooperation with the Bureau of Reclamation, Glen Canyon Environmental Studies Office, Flagstaff, Arizona.

Fairley, H.C., 2003, Changing river-Time, culture, and the transformation of landscape in the Grand Canyon: Tucson, University of Arizona Press, 179 p.

Fairley, H.C., 2005, Cultural resources in the Colorado River corridor, in Gloss, S.P., Lovich, J.E., and Melis, T.S., eds., The state of the Colorado River ecosystem in Grand Canyon: U.S. Geological Survey Circular 1282, p. 177-192., available at http://pubs.usgs.gov/circ/1282/.

Gatewood, J.S., 1962, The meteorologic phenomenon of drought in the Southwest: U.S. Geological Survey Professional Paper 372-A, p. 1-43. 
Gatewood, Wilson, A., Thomas, H.E., and Kister, L.R., 1963, General effects of drought on water resources of the Southwest: U.S. Geological Survey Professional Paper 372-B, p. 1-55.

Graf, J.B., Webb, R.H., and Hereford, R., 1991, Relation of sediment load and flood-plain formation to climatic variability, Paria River drainage basin, Utah and Arizona: Geological Society of America Bulletin, v. 103, p. 1405-1415.

Guttman, N.B., and Quayle, R.G., 1996, A historical perspective of U.S. climate divisions: Bulletin of the American Meteorological Society, v. 77, p. 293-303.

Hazel, J.E., Jr., Kaplinski, M., Parnell, R.A., and Fairley, H.C., 2008, Aggradation and degradation of the Palisades gully network, 1996 to 2005, with emphasis on the November 2004 High-Flow Experiment, Grand Canyon National Park, Arizona: U.S. Geological Survey Open-File Report 20081264, $14 \mathrm{p}$.

Hereford, R., 1984, Climate and ephemeral-stream processes-Twentieth-century geomorphology and alluvial stratigraphy of the Little Colorado River, Arizona: Geological Society of America Bulletin, v. 95, p. 654-668.

Hereford, R., 1986, Modern alluvial history of the Paria River drainage basin, southern Utah: Quaternary Research, v. 25, p. 293-311.

Hereford, R., 2006, User's guide, software for reduction and analysis of daily weather and surface-water data-Tools for time series analysis of daily precipitation, temperature, and stream-flow data: U.S. Geological Survey Open-File Report 2006-1101, 16 p., available at http://pubs.usgs.gov/of/2006/1101/.

Hereford, R., 2007, Climate variation at Flagstaff, Arizona-1950 to 2007: U.S. Geological Survey Open-File Report 2007-1410, 17 p., available at http://pubs.usgs.gov/of/2007/1410/.

Hereford, R., Fairley, H.C., Thompson, K.S., and Balsom, J.S., 1993, Surficial geology, geomorphology, and erosion of archeologic sites along the Colorado River, eastern Grand Canyon, Grand Canyon National Park, Arizona: U.S. Geological Survey Open-File Report 92-339, 46 p., maps.

Hereford, R., Jacoby, G.C., and McCord, V.A.S., 1996, Late Holocene alluvial geomorphology of the Virgin River in the Zion National Park area, southwest Utah: Geological Society of America Special Paper 310, 46 p.

Hereford, R., Webb, R.H., and Graham, S., 2002, Precipitation history of the southern Colorado Plateau region, 1900-2000: U.S. Geological Survey Fact Sheet 119-02, 4 p., available at http://pubs.usgs.gov/fs/2002/fs119-02/.

Hereford, R., Webb, R.H., and Longpré, C., 2003, Precipitation history of the Mojave Desert region, 1893-2001: U.S. Geological Survey Fact Sheet 117-03, 4 p., available at http://pubs.usgs.gov/fs/fs117-03/.

Hereford, R., and Webb, R.H., 2003, Map showing Quaternary geology and geomorphology of the Lonely Dell Reach of the Paria River, Lees Ferry, Arizona, with comparative landscape photographs: U.S. Geological Survey Geologic Investigations Series I-2771, scale 1:5,000, available at http://pubs.usgs.gov/imap/i2771/.

Hereford, R., Webb, R.H., and Longré, C., 2006, Precipitation history and ecosystem response to multidecadal precipitation variability in the Mojave Desert region, 1893-2001, in Berry, K.H., and Murphy, R., eds., Desert of the world part I, the changing Mojave Desert: Journal of Arid Environments, v. 67, p. 13-34.

House, P.K., 1993, The Arizona floods of January and February 1993: Arizona Geological Survey, Arizona Geology, v. 23, 5 p.

Hunt, C.B., 1967, Physiography of the United States: San Francisco, W.H. Freeman, 480 p.

Kunkel, K.E., Easterling, D.R., Hubbard, K., Redmond, K., Andsager, K., Kruk, M.C., and Spinar, M.L., 2005, Quality control of pre-1948 cooperative observer network data: Journal of Atmospheric and Oceanic Technology, v. 22, p. 1691-1705. 
Lowe, C.H., Brown, D.E., 1994, Introduction, in Brown, D.E., ed., Biotic communities—Southwestern United States and Mexico: Salt Lake City, University of Utah Press, p. 8-16.

Mantua, N.J., and Hare, S.R., 2002, The Pacific decadal oscillation: Journal of Oceanography, v. 58, p. 35-42.

Melis, T.S., Phillips, W.M., Webb, R.H., and Bills, D.J., 1996, When blue-green waters turn red, historical flooding in Havasu Creek, Arizona: U.S. Geological Survey Water-Resources Investigations Report 96-4059, 136 p.

Mock, C.J., 1996, Climatic controls and spatial variations of precipitation in the Western United States: Journal of Climate, v. 9, p. 1111-1125.

Pederson, J.L., Petersen, P.A., and Dierker, J.L., 2006, Gullying and erosion control at archaeological sites in Grand Canyon, Arizona: Earth Surface Processes and Landforms, v. 31, p. 507-525.

Pyke, C.B., 1972, Some meteorological aspects of the seasonal distribution of precipitation in the western United States and Baja California: Los Angeles, University of California, Water Resources Center contribution No. 139.

Roof, S., Callagan, C., 2003, The climate of Death Valley, California: Bulletin of the American Meteorological Society, v. 84, p. 1725-1739.

Sheppard, P.R., Comrie, A.C., Packin, G.D., Angersbach, K., and Hughes, M.K., 2002, The climate of the US Southwest: Climate Research, v. 21, p. 219-238.

Shinker, J.J., Bartlein, P.J., 2010, Spatial variation of effective moisture in the western United States: Geophysical Research Letters, v. 37, L02701, doi:10.1029/2009GL041387.

Swetnam, T.W., Betancourt, J.L. 1998, Mesoscale disturbance and ecological response to decadal climate variability in the American Southwest: Journal of Climate, v. 11, p. 3128-3147.

Topping, D.J., 1997, Physics of flow, sediment transport, hydraulic geometry and channel geomorphic adjustment during flash floods in an ephemeral river, the Paria River, Utah and Arizona: Seattle, University of Washington, Ph.D. dissertation, 405 p.

Trenberth, K., and Hoar, T., 1996, The 1990-1995 El Niño-Southern Oscillation event—Longest on record: Geophysical Research Letters, v. 23, p. 57-60.

Webb, R.H., Smith, S.S., and McCord V.A.S., 1991, Historic channel change of Kanab Creek, southern Utah and northern Arizona: Grand Canyon, Arizona, Grand Canyon Natural History Association Monograph Number 9, 91 p.

Webb, R.H., and Betancourt, J.L., 1992, Climate variability and flood frequency of the Santa Cruz River, Pima County, Arizona: U.S. Geological Survey Water-Supply Paper 2739, 40 p.

Webb, R.H., Griffiths, P.G., Melis, T.S., and Hartley, D.R., 2000, Sediment delivery by ungaged tributaries of the Colorado in Grand Canyon: U.S. Geological Survey Water-Resources Investigations Report 00-4055, 67 p.

Webb, R.H., Leake, S.A., and Turner, R.M., 2007, The ribbon of green-Change in riparian vegetation in the Southwestern United States: Tucson, University of Arizona Press, 462 p.

Woodhouse, C.A., Kunkel, K.E., Easterling, D.R., and Cook, E.E., 2005, The twentieth-century pluvial in the western United States: Geophysical Research Letters, v. 32, L07701, doi:1010.129.

Wu, H., Hubbard, K.G., and You, J., 2005, Some concerns when using the Cooperative weather station networks - A Nebraska case study: Journal of Atmospheric and Oceanic Technology, v. 22, p. 592602. 